\title{
Decolonial voices, colonialism and the limits of European liberalism
}

\section{The European question revisited'}

\author{
Jan Ifversen
}

Let me begin by quoting Mekki Ali, a Sudanese refugee interviewed in the so-called Calais Jungle. He says: 'I say to the British government, they have to accept the people and particularly the Sudanese, to accept them or to find a solution for a way ahead to the future, because [the] Sudanese were colonized by Britain'. ${ }^{2} \mathrm{He}$ is addressing Britain, but his query is certainly also relevant to Europe. It is part of a European question.

The European question relates to European integration. In European historiography, major challenges are typically called 'questions' - questions that are indeed often synonymous with major political and social problems in need of solutions (Anidjar 2013). Modern European history provides a series of such questions or problems. In the nineteenth century, for instance, the so-called national question signalled efforts to gain entry into the recognized geopolitical order. Communities that found themselves geopolitically misplaced posed this question to become nation-states. Only the countries controlling the power balance could, however, answer this question and decide which were entitled to be called nations. In a Europe made up of nationstates conducting national identity politics, non-national others constituted fundamental political problems. Nineteenth-century European history is suffused with questions of 'misfits' such as women, Jews, Muslims, and the colonized, all categories deemed unfit to become full members of the community according to the dominant national matrix. All were designated as questions or problems requiring solutions.

While questions of the existing misfit might be answered or 'solved' over time, new categories of misfits have regularly appeared in their place. Today there is much talk about the migrant question, or rather the migrant crisis, in Europe. Questions that become difficult to solve often tend to be conceptualized as crises that designate dilemmas characterized by indecision, uncertainty, and insecurity (Ifversen 2017). The path of European integration of late has followed a crisis rhythm, with the migration crisis being the most recent in a series of problems that fundamentally destabilize the idea of European unity. The question of the 'misfit'-in this case, the migranttherefore also challenges the very idea of Europe and its emphasis on European integration and reopens the European question. This latest crisis 
can, however, also be viewed as a return to an older question. As stated by Nicholas de Genova in his reflections on the status of the European question, it is 'increasingly fashioned against the postcolonial specter of a mob of mobile (nonwhite) non-Europeans' (De Genova 2016, 88). The 'mob of mobile non-Europeans' describes those migrants who for many Europeans have become such a problem they produce a crisis for Europe. In dominant political discourse, they are considered outsiders. This 'outside' is, however, questioned by Mekki Ali, the Sudanese refugee quoted above. The Sudanese are here, he says, because the British colonized the country he fled. The migration crisis makes visible entanglements between Europe and places formerly colonized by European powers. Until at least the 1970s when the last colonial wars ended and most of the former colonies became independent states, many European states faced the colonial problem, one that in 1950 Aimé Césaire considered the main problem facing European civilization in his famous Discours sur le colonialisme (Césaire 1972). The colonial entanglement thus returns to haunt the European question in the form of a 'blind alley': 'Whether one likes it or not, at the end of the blind alley that is Europe, I mean the Europe of Adenauer, Schuman, Bidault, and a few others, there is Hitler' (Césaire 1972, 37). What Césaire here points to is the risk that the new, post-war project for Europe stays nothing but an illusion based on repressing past inhumanities. The resistance of the colonized - in Europe and the colonies - will continuously remind the post-war Europeanists of this repression. A European question, which does not reflect on those excluded from Europe, will thus end in a blind alley.

This chapter investigates the European question in light of the 'problematic' questions of those categorized as unfit to be in Europe. I want to discuss similarities between the questions raised against problematic 'others' and to look closer at the dynamics of exclusion which still create blind alleys for an idea of Europe. In mainstream European politics, the others, 'the misfits', have either been repressed from history or kept in a constant interim position with no voice in discussing the European question. If we are to have any hope in the transnational and intercultural potential contained in the idea of Europe, it is time to listen to those who have been marginalized and silenced. This is particularly true for a European like me safely anchored in Northern Europe.

\section{The Jewish question}

We can understand these questions as interpellations of uncertainties in the political ordering of Europe. The expansionist strategies of inclusion that characterized both European imperialism and liberalism always carried with them ideas of borders, limits, and differences. Dynamics of equality and of assimilation operated with difference as their backdrop. Groups could only attain access to a community (and its state) if their differences could be overcome. The inclusion of the poor 'dangerous classes' relied on the formalization of equality within abstract citizenship. Granting women access to the 
public and political sphere was based on a disembodiment, where 'women's difference is not ... a public difference' (Brown 2004, 17). In both cases, the strategy of the liberal state proved successful. Neither the worn-out bodies of the poor nor the gendered bodies of women would disturb the fiction of inclusion that liberalist ideology promoted. The presence of other groups, however, challenged the limits of this fiction. At the international level, the geopolitical management of difference operated as a standard of civilization set by the European empires (Gong 1984). Since the nineteenth century, the colonial empire with its mission to civilize became embedded in the liberal nation-state. With both belonging and sovereignty filtered through the symbolic coordinates of nation and people, it became crucial to establish state technologies for managing diversity. The question of belonging (or not) found its answer in the ideology of the liberal state with its formalized conceptions of citizenship and its specific biopolitical practices. Dynamics of equality and of assimilation operated against a background of difference. Groups or categories only won access to the national community (and its state) if their differences could be mastered. The first group to pose a serious challenge to the liberalism of the nation-state was neither the working class nor women but those categorized as Jews. The Jewish question became the first test of how far the European liberal state would go in its practice of assimilation and exclusion.

While the colonial question was primarily discussed among colonial administrators, proto-ethnographers, and - somewhat later-legislators and educators (Saada 2003), the Jewish question became a general topic in public discussion. In fact, this question was less about a specific marginal group than about ways of managing diversity. As Jean-Paul Sartre demonstrates so clearly in his book Réflexions sur la question juive, written in 1944 within close range of the terrible Endlösung, the category of the Jew was an invention produced by public opinion, not a 'historical fact' (Sartre 1948, 11). For nationalists, the Jew is a scapegoat necessary for the imaginary of a pure nation. Anti-Semitism is thus the logical racist supplement of nationalism. This is in line with the argument made by Hannah Arendt in her analysis of the liberal state that is conquered by the nation through nationalism, 'which is essentially the expression of this perversion of the state into an instrument of the nation' (Arendt 1958, 231). The perversion is exemplified both by antiSemitism in Europe and by racism in the colonies. Sartre makes the same gesture when he states that for the racist, the Jew is a 'pretext' that elsewhere can be replaced by blacks or Asians. The Jew is thus not only a question for the anti-Semite. The nineteenth-century European nation-state vacillated between two solutions to the Jewish question: the racist exclusion and the liberal, or what Sartre calls the 'democratic', assimilation option. The latter strategy is, however, not more recognizant of difference. As Sartre so elegantly puts it, the anti-Semite

wishes to destroy him as a man and leave nothing in him but the Jew, the pariah, the untouchable; the latter [the democrat] wishes to destroy him 
as a Jew and leave nothing in him but the man, the abstract and universal subject of the rights of man and the rights of the citizen.

(Sartre 1948, 40-41)

In both cases, the Jew is eliminated. Sartre's criticism of the emptiness of liberal universalism - based as it is on a fiction of abstract man that discards difference and inequality-mirrors Marx's famous analysis of the Jewish question as the problem par excellence that kept disturbing this fiction (Marx 1994).

Sartre points to the social psychology of racism where the anti-Semite is caught within a structure of destructive desire and the 'Jew' is trapped in an objectified gaze. Assimilation is simply a zero-sum game for people categorized one way or the other. If a person accepts the offer of assimilation, he or she still has to 'look at himself through the eyes of others' and cultivate 'himself in order to destroy the Jew in himself' (Sartre 1948, 70). For the Jew, this means escaping into the universal in an effort to refute any attachment to what society labels Jewishness. Sartre speaks of a masochism-mirroring the sadism of the anti-Semite - where Jews constantly objectify themselves to match the dominant gaze of society. The Jew who responds to the offer of assimilation denies any particularity and exists as a pure abstract in society willing to renounce his or her liberty. The mission is, however, impossible since the Jew remains unassimilable in the eyes of the nation-state. Thus, the Jew is haunted by the image that society creates for him or her when answering the Jewish question. In 'The Jew as Pariah', written the same year as Sartre's text, Hannah Arendt pointed to the same blind alley of assimilation. The Jew who pursues assimilation she calls a parvenu who simply 'ape(s) the gentiles' and plays the role expected by society. This is the "modern would-be assimilationist Jew' she compares to the figure of the Schnorrer, a Yiddish term that mirrors the anti-Semite stereotype of the Jew. Becoming a Schnorrer is for Arendt to become 'one of the props which hold up social order from which he is himself excluded' (Arendt 1944, 110, 116).

Sartre also highlighted the predicament of the inauthentic Jews who constantly negate the Jewishness assigned to them by society while at the same time being obsessed with the consciousness of being just that, Jews. Inauthenticity leaves another possibility, namely the authentic Jew who revolts and asserts himself or herself as particular within society. This means choosing oneself to identify as a Jew and rebelling against the universalist illusion of liberal society. 'He is what he makes of himself', as Sartre puts it (Sartre 1948, 99), while Arendt goes further and turns the rebelling Jew into a pariah who uses his or her marginal position to intervene in society. Arendt's pariah is the Jew who 'transcend(s) the bounds of nationality' while at the same time embedding himself or herself in Europe (Arendt 1944, 99). Pariahs reject the image of the purifying nation and avoid the 'double slavery' of either trying to become assimilated or to completely opting out of society and constructing a separate nation. Being a pariah does not mean accepting 
marginality, since the pariah has the advantage of an external position that brings with it 'a transformative movement' (Zolkos 2011, 198). As such, the pariah is aloof and never quite at home in the world. He or she is, by turns, the poet who criticizes the world from without; the rebel who attacks oppression; or the schlemiel-the awkward, seemingly helpless, clumsy Jew, the Chaplin-esque fool-who incidentally reveals the injustices of society (Zeldner 1953). Whichever the case, the pariah signals a position of resistance and of hope for 'a true blending of cultures' (Arendt 1944, 106).

\section{The colonial question and the colonized race}

Europe's colonial question concerned how to justify sovereignty over colonial subjects and how to govern colonized peoples (Scott 1995). Lord Cromer, the arch-bureaucrat of the British Empire, both emphasized the right of the superior 'Anglo-Saxon race' to rule the 'subject races' and outlined regular policies for the treatment of these races (Cromer 1913, 17). That racism was an integral part of the technologies of power executed in the colonies has been demonstrated with devastating effect by the polyphonic voices of the colonized. Just as the Jewish question turned racism into a tool of exclusion within Europe, then, racism was an answer to a colonial question that both consecrated white dominance in the colonies and restricted access to the metropole. While 'far from view' for many Europeans, the racist prerequisites of the slave trade, slavery, and other brutalizing elements of colonial systems constituted the matrix of modern European racism (Goldberg 2006).

The Jewish question took centre stage in nineteenth-century Europe because the Jewish minority was proximate. But as ties between the imperial metropole and its peripheries grew tighter, the colonized came to Europe in increasing numbers. Consequently, assimilation would become a more pressing issue within the colonial question. When Frantz Fanon wrote Peau noire, masques blancs in 1952, he directly addressed the colonial matrix as the white construction of blackness. As he stated near the outset, a black soul is 'a white man's artifact' (Fanon 1986, 16). Throughout the text he aimed to deconstruct the 'fixed concept of the Negro' that held the colonized in 'crushing objecthood' through a classifying, imprisoning, primitivizing, and decivilizing mode (Fanon 1986, 35, 109, 32). Being designated black, Fanon insisted, was to be reduced to one's body beyond any representation. A black person was simply black skin, slave to his or her appearance (Fanon 1986, 116). The double enslavement - both as a slave of the white and as a slave to his or her body - produced an inferiority complex similar to the masochism of the Jew. Through this complex, the black person was placed in a constant state of lack when compared to a white person. When the educated black tries to assimilate and become like the whites-Fanon calls it 'lactification' and wearing a 'white mask' (Fanon 1986, 47) - he or she is caught in the same cul-de-sac as Arendt's Jewish parvenu. There is no escape from blackness, which simply denotes a problematic being. The body of the black person is 
essentially problematic for the white person because it represents depravity and destruction. Fanon exposes the psychopathology of European racism in its reduction of the black to a male body of pure sexual aggression, 'a penis symbol' that threatens the entirety of white society. Blackness thus becomes the negation of social life.

These similarities between the Jewish and the colonial questions have been highlighted by several observers, including Fanon himself in his engagement with Sartre's reflections on anti-Semitism (Cheyette 2005; Gibson 2003; Rothberg 2009). At times, he views anti-Semitism and black racism as structurally identical. While the categories of black and Jew are both overdetermined, the Jew is not locked into his or her body and is not perceived as a biological but rather an ideological danger (Fanon 1986, 165). In so doing, Fanon - in line with Sartre - appears to discard the sexualized and corporeal symbolic that long nourished anti-Semitism in his effort to make black racism the matrix for European racism, thereby placing the Jew in a position between being black and being (more) white (Gibson 2003). Yet Fanon simultaneously held on to the view that the Jew was his brother in misery. European racism is thus structural in the sense that it demonstrates the racial logic of assimilation. When Fanon concluded his book by stating that the 'the negro is not' (Fanon 1986, 248), he points to both the role of racism within the European concept of humanity and his own liberation from this false humanism. And like Sartre and Arendt, he argues for the authenticity of the pariah as the only way out. Fanon's pariahs can still be poets among the dominant but as we know from Les damnés de la terre, they are primarily the revolutionaries who do not seek recognition, preferring to leave Europe to itself in order to build 'a new history of man' (Fanon 2004, 238).

\section{Post-war Europe: all questions solved?}

After the so-called final solution, it was no longer possible to ask the Jewish question in Europe. It translated into the memory of the Holocaust as a constant reminder of the guilt carved into European identity. Perhaps it would be more precise to say that the question found its answer in a political myth of a Europe both radically reborn yet nonetheless still founded on the traumatizing event of the Holocaust. On the one hand, Europe's 'virgin birth' (Onar and Nicolaïdis 2013, 292) made it possible to disconnect from the past, close the Jewish question, and pave the way for a re-universalized future. On the other hand, the memory of the Holocaust made room for a rewriting of European history. David Theo Goldberg adds that this rewriting dissipated the entire question of race in Europe. Only pre-war anti-Semitism could be granted the status of European racism; all other forms of racial exclusion would be disavowed. 'Racial europeanization has rendered race unmentionable, unspeakable if not as reference to an anti-Semitism of the past that cannot presently be allowed to revive', he argued (Goldberg 2006, 339). With race eliminated as a political concept and the surviving Jews 
reduced to actors in a European memory theatre - a term borrowed from Max Czollek, who points to the function of the Jew in the German memory theatre as guarantor of a healed Germany (Czollek 2018) - the scene was set to make colonialism and the colonial other vanish from the European horizon.

Post-war Europe with its compensatory surplus of Holocaust memory (Judt 2005, 289) was, therefore, also characterized by a deficit, the effacement of its colonial history (Buettner 2016; Prutsch 2015). Decolonization would be the chapter title historians would insert to signal the end of old Europe and the beginning of a new, disentangled Europe. Colonial legacies would re-emerge in the shape of migrants or Muslims, Europe's new poor, always disconnected from Europe; or in neo-colonial relations camouflaged as developmental policies. As early as 1950, Césaire tried in vain to remind Europeans 'that no one colonizes innocently ... that a civilization which justifies colonization ... is already a sick civilization' (Césaire 1972, 39). With racism relegated to the most paranoid corners of ultra-right anti-Semitism and the Jewish question replayed in the European memory theatre, the question of the unfit could be closed. With the uplifting of the Holocaust to a founding myth for Europe and with nationalism filling in where racism was subtracted, the way was paved for a compromise between the supranational visions of the new Europeanism and the older Europe des patries. The former could be expressed as a European universalism capable of at least simulating a new mission to civilize (Kølvraa 2012; Nicolaïdis et al. 2014), as long as references to past European imperialisms could be silenced. The compromise between supranational institutions and nationalism found its motto of 'unity in diversity' where the latter could extend no further than the diversity contained within the nation-states (Fornäs 2012). Then came crises: first the financial crisis of 2006-2008, which challenged internal unity between Northern and Southern Europe, and in 2015 the so-called refugee crisis, which heralded a dramatic inward-looking turn in European policies. The question of the other was thereby re-opened.

\section{The migrant crisis: a choc en retour?}

The migrant crisis forced Europeans to confront the presence of colonial entanglements and highlighted the postcolonial challenges to European identity (Bhambra 2009). Colonial history comes back as a choc en retouror boomerang effect-already exposed in Césaire's indictment of European civilization. With the full revelation of Nazi crimes, Europeans brutally experienced the effects of the racism that they had long practiced elsewhere. They became exposed to their 'own habit of seeing the other man as an animal, ... treating him like an animal, and ... objectively to transform himself into an animal' (Césaire 1972, 41). In her work on the origin of totalitarianism, Arendt directly linked the choc to the imperialist 'experiments' conducted by the Europeans in Africa that prefigured the full unleashing of 
the racist dynamics embedded in nationalism (Arendt 1969). The choc, according to Arendt, was part and parcel of nationalism's true nature. Europeans, however, overcame the first choc with an impressive strategy of repressing the colonial legacy and became born-again universalists. Only marginal voices such as Césaire's insisted on reminding Europeans of their inhumanity.

The refugee crisis - soon to become the migrant crisis - created yet another choc en retour. Even if migration has been a dominant feature of European history since at least the early nineteenth century it had not fundamentally threatened the national imaginary. By contrast, political rhetoric feeding the current crisis creates a generalized image of the migrant as unstable and unsettled, with the migrant becoming caught between two opposed perspectives. Within the dominant discourse, the migrant is basically a person on the move without attachment to any place. People migrating, on the other hand, come with a purpose of settling. The migrant concept, however, leaves little discursive space for the natural end goal of settlement. In ordinary parlance, migration extends over generations. As Fatima El-Tayeb puts it, the concept is 'at once implying a temporary and a permanent condition: migration appears as always reversible, coming with an expiration date, but at the same time stretching over several generations' (El-Tayeb 2008, 652). This constitutes a conceptual deadlock: whatever else you might have been, or might wish to be, you essentially stay a migrant. The concept marks a condition of temporality and in-betweenness as well as a point of asociability. The migrant is reduced to bodily presence without any status or story.

This migrant is not stateless, but we can find many similarities between the current migrant and the stateless that Hannah Arendt pointed to as the crucial pivot in modern European history. Based on an analysis of the nationality question unleashed in Europe after the First World War, she emphasized the deficit resulting from the final nationalization of the liberal state. The deficit was made up for first by national minorities desperately in search of a state or - if this proved impossible - in search of international protection; and second, by people left over, namely the stateless people completely lost in their situations of being simultaneously homeless, stateless, and without rights. Just as in the migration crisis of 2015, the right of asylum was the first casualty. For Arendt, this European crisis led to 'the realization that it was impossible to get rid of them or transform them into nationals of the country of refuge' (Arendt 2007, 281). The stateless person is unwanted and 'superfluous' in every way. He or she is an outlaw, outside legality and forced to break the law for survival, and without history. In her very personal text, 'We Refugees' from 1943, Arendt explores the experience of refugees being asked not to tell their stories. Like today's migrants, they are both out of time and out of place. However, worst of all, since stateless people are outlawed, they have also lost their right to have rights, which marks the absolutely lowest point of humanity. They are, in Arendt's words reduced to 
'abstract nakedness' and to being nothing but human beings (Arendt 2007, $300,297)$. In a sense, this reduction is comparable to the one performed through racialization: people's presence is enough to condemn them, but here the reduction goes even further than the slave whose body is still worth oppressing.

If, in the migration crisis since 2015, the stateless can still officially seek asylum and thus speak about the past, the dominant discourse tends to reduce them either to bodies to be incarcerated in internment camps or to being out of place wherever they are present. The remaining option is to refer the migrant question back to older questions in which case migrants are equated with Muslims and essentialized through Islamophobia or with blackness and essentialized through racism. The discursive strategy at play is thus to outline a contradiction marked on one side by the reductive concept of the migrant and the other side by the 'fullness' of race.

\section{Back to the Muslim question}

European answers to the Jewish and the colonial question moved from the internal, racial logic of assimilation to the utter genocidal violence of the Holocaust and colonial massacres. Jews and colonized Africans were certainly not the only others who challenged the liberal imaginary of the European nation-states. Although 'the Muslim question' is a term used mainly by scholars to denote the growing racialization in late twentieth-century Europe of citizens and migrants based on religion, it is rooted in a historical question of 'the Muslim' as the external political enemy (Anidjar 2013; Bracke and Aguilar 2020; Norton 2013; Selby and Beaman 2016). As a historical question, 'the Muslim' is both embedded in a European Orientalism that forms an important matrix of colonial domination and an earlier fear of 'the Turks' (Yapp 1992). In a structural sense, the Muslim question is coterminous with the Jewish and the colonial question. Together they form a triangle of challenges faced by liberal assimilation policies where racialization includes religion, culture, and origin (Meer 2013). Anti-Semitism and Islamophobia are the twin forms of a racialization based on religion, which secures a European imaginary of both being secular and Christian, of being abstractly universal and essentially cultural at the same time. In both cases, the racialization works to combine bodily demarcations (physical and sexual deformities as well as erotic fantasies) with religion and culture (and often religion as culture).

While the questions were certainly entangled in European colonial governmentality (Katz 2018), 'the Muslim question' also has a separate history of becoming the empty signifier of racism in a Europe that officially silenced racism after 1945. As Goldberg succinctly remarks, any articulation of race within Europe was rendered 'unmentionable, unspeakable if not as a reference to an anti-Semitism of the past' that only lived on in small pockets at the most extreme right (Goldberg 2006, 339). In this atmosphere of a 
universalism aimed at providing healing in the present and open up a new future through the memory of the Holocaust and the oblivion of colonialism, the Muslim question reappears as a reframing of the problem of migration. When migration is rendered a problem with the end of the economic miracle for West Europeans in the 1970s, we see a systematic 'muslimification' of migrants who had previously been viewed either through their postcolonial or their national origins (Adamson 2011; Parekh 2006). The specific attachment of the Muslim question to migration has led scholars to speak of this form of racialization as a new racism that does not need a bodily or 'biological' reference. Étienne Balibar, who was prominent in introducing the term, insists on a difference between a racism built around biological heredity and a racism claiming cultural difference as 'insurmountable' (Balibar 1991, 21). Later, the term 'cultural racism' gained prominence in discussions of discrimination against people based on religious categorizations (Birt 2009; Modood 2008). In light of the prominent role that Islamophobia has assumed in Europe since Balibar alluded to a new racism more than 30 years ago, it makes less sense, however, to underline the semantic variations with older forms of racism. The concentration of exclusionary mechanisms in the nodal point of Islamic fanaticism happens through a set of equivalences that includes classic racist depictions of deformed bodies - a case in point is the Danish Mohammed cartoons from 2005-and direct references to fertility and sexuality, the latter configured in fantasies of a demographic 'replacement' of the 'pure' European population (Bracke and Aguilar 2020).

These different questions of the unfit derive from dissimilar historical contexts, but they interrelate in the assimilation strategies that liberal European states tested out in the nineteenth and twentieth centuries. It is therefore difficult to make one the prototype of the others. Is European antiSemitism the prototype of a 'non-biological racism' as Balibar claims (1991, 24)? Alternatively, is, as Goldberg would argue, the racism of colonial governmentality the paradigmatic one (2006)? There are certainly distinctions. Fanon pointed to the difference between being completely caught within one's body as was the case with racism against black people and being caught in religion. Jews in Western Europe could negotiate their parvenu status differently than people from the colonies. They could potentially hide under the abstract umbrella of the liberal state, which only granted very limited access to colonized people. In the end, the only options left for the unfit towards the assimilation technologies of the liberal state are between the parvenu and the pariah.

People targeted by the Muslim question indeed changed their responses. We see a move from passive observations of mounting Islamophobia by a fragile group of postcolonial migrants in the wake of 11 September 2001 and the Western involvement in Iraq and Afghanistan that led to the forceful consolidation of a Muslim identity in the European public sphere. The adoption of a Muslim identity as a political marker by marginalized groups in European societies made an important contribution to shifting the 
assimilation agenda from an insensitive and abstract universalism to a politics of recognition and identity (Birt 2009; Modood 2008). More recently, both established and rising populist parties have demonstrated a strong tendency to regard identity politics as both a direct attack on liberal values, often condensed in free speech absolutism, and what the majority sees as a perverted effort by minority groups to undermine community cohesion. Due to the spread of Islamophobia to established parties in Europe, responses among minorities identifying as Muslims have taken the form of more direct protests against discrimination and a reinforcement of the transnational dimensions of this identity.

\section{We are here}

In September 2012, a group of undocumented migrants in Amsterdam initiated a protest movement under the motto, 'We Are Here'. By taking up residence in abandoned buildings they began to make their presence publicly visible (Dadusc 2017; Odugbesan and Schwiertz 2018). In the name of the undocumented, they published a manifesto stressing that 'We demand our existence to be acknowledged in official policies and laws. We are here and we will remain here' (quoted in Dadusc 2017, 275). Being undocumented or-in the eyes of the state-illegal is the most radical expression of asociability. By challenging public disengagement and criminalization by the state, the undocumented turned their position into a strategy of resistance. Crucially, when migrants added the phrase 'because you were there' to their rallying cry, they shifted the perspective from universal morality to history and memory. The migrants bring with them a historical legacy of entanglement the Europeans had repressed in order to reduce them to anonymous characters without history or rights.

Resisting anonymity and bringing in history are steps in a strategy of resistance conducted by the allegedly unfit to protest against brutal integration policies. If we are to reflect on transnational possibilities in Europe, we need to listen to the voices of the groups that from the beginning of European modernity presented alternatives to assimilation and abstract universalism. These are the groups that modern Europe branded pariahs, parasites, and criminals. Hannah Arendt advocated the position of the conscious pariah who would use his or her role both as outsider to criticize the homogenizing effects of the nation-state and as a rebel who would resist. It would be a poetic outsider like Heinrich Heine who would denounce 'the nonsense' of cosmopolitanism - the most grandiose version of abstract universalism - to 'transcend the bounds of nationality' and favour 'the true blending of cultures' (Arendt 1944, 99, 106). The conscious pariah is the one who turns the 'aloofness' of the poet into politics and fights for political rights to be different. This involves rebelling against assimilation, but even more against the hypocrite play performed by the parvenus who have surrendered to the pressure of the majority. The pariah is always fighting this double slavery 
imposed by both the majority and the parvenus. Arendt presented the pariah as a necessary structural position or 'ideal human type' within European modernity that could be filled with different stories (Bernstein 1996, 29). In its most pure form, the structural pariah would come in the guise of the "stateless"' (Arendt 1944, 111).

The concept of the pariah has this rhetorical capacity of turning exclusion into a strategy of both resistance and alternative thinking. When Europeans speak of the parasite, they use an even more figuratively racist term. Where the pariah is an outcast, the parasite is a metaphor that turns communities into destroyers of life. The term came to play an important role in the antiSemitic perception of Jews as not simply aliens or less civilized but also as capitalists who literally destroyed the body of the people. As parasites, they live off the body of their host and finally kill it. The term became a nodal point in the anti-Semitic bio-mythologization of race and society with its crucial linking of blood, body, and exploitation (Bein 1964) and reached a climax in Nazi ideology. In Mein Kampf, Hitler would write that the Jew 'remains the eternal parasite, a sponger (Schmarotzer) who, like a terrible bacillus, spreads out more and more as soon as a favourable medium invites him to do so' (quoted in Bein 1964, 19).

While the parasite here is a symbol of impurity, intrusion, and destruction, just as with the pariah we can read it counter-intuitively, as Michel Serres does in his book Le parasite (Serres 1982). For Serres, the figure serves to signify a relationship of dependence. In the conventional sense, the parasite is dependent on the host, but the host is also dependent on somebody else. All relations are thus parasitic or, as Serres puts it, 'we parasite each other' to the extent that it becomes foundational, 'the atomic form of our relations' (Serres $1982,10,8)$. In his theory of relationality, parasitism thereby differs from relationships based on gift-giving or exchange. The former operates through the continuous circulation of tokens that uphold obligations; the latter are relations accounted for through symbols of exchange. Parasitism in this reading is not only asymmetrical - taking without giving-it is also disturbing. We tend to see societies as either based on the dynamics of gift giving or on the exchange of goods or words, but Serres introduces parasitism as a third form of relationality where dependency is the basic dynamics. Such cascades of dependency have been vigorously depicted in Bong Joon-Ho's Oscar-winning 2019 film Parasite, which makes the crucial point that, despite belonging to different social classes, we are all parasites.

Parasitism does not simply outline a social theory that opposes theories based on asymmetrical exchange (the Marxist theory of exploitation) or symmetrical exchange (the liberal theory of individuals or citizens interacting). Parasitism is also a theory of dynamic differences. In Serres's rendition, the parasite is also an interceptor that disturbs order $(1982,11)$. Inspired by information theory, Serres speaks of the noise that comes with parasitic relations. On the one hand, noise disturbs the ideal of smooth and transparent interaction. In a social logic of exchange - for instance, between free and equal 
citizens - noise needs to be overcome. When unity or identity become the ordering principle, the noise of the parasite is threatening and has to be expelled. The parasite is a symbol of disorder while also being the necessary transformer and inventor of something new. It is therefore an impossible but dangerous idea to eliminate the noise brought about by the parasite. Turning the otherness of the noise and the parasite into contradiction leads to fantasies of 'immunization' (Burton and Tam 2016, 122). Only if the parasite is recognized as a factor that challenges both these imaginaries and brings with it social creativity, can we think beyond the 'condescending liberalism', as Sartre described it, and towards a society based on interculturality (Sartre 1948, 98).

\section{Transnationality and interculturality}

Hannah Arendt turned the pariah into both a privileged observer of plurality and a political actor of transnationality. Serres more generally pointed to the creative role of 'the parasite'. Critiques of current assimilation policies see the migrant or refugee as 'the critical vantage point' through which Europe can be decentred (De Genova 2016, 92). In light of the catastrophic final solution to the Jewish question, Arendt saw some hope - a pardon and a promise - in the ideas of a European federalism that would replace the nation-state (Rensmann 2006; Selinger 2016). In the post-war struggle against nationalism and fascism, 'the slogan was simply Europe' (Arendt 1994, 112). Arendt's endorsement of European federalism, however, concerned more the Jewish minority. Her slogan included neither postcolonial outsiders in Europe nor those on the colonial 'peripheries'. Europe today is hardly the solution anymore, but rather a question to be re-posed. If we wish to invigorate the transnational possibilities linked to a certain idea of Europe, we must listen to Europe's new pariahs and parasites. Only they carry hopes for a Europe that is decolonial and intercultural. Balibar has proposed an intercultural model for Europe based on the potential embedded in its character of being a borderland (Balibar 2009). Reflecting on the fact that borders of the European political space are overlapping and permeable - both in the sense of free movement of labour and migration - he regards this as potential for an intercultural normativity. With his term 'borderland', Balibar proposes a way out of the risks linked to supranationalist visions of Europe as a global power (Kølvraa 2012) or to cosmopolitan exaltations of its normative power (Beck and Grande 2007). The borderland is a zone "where the opposites flow into one another, where "strangers" can be at the same time stigmatized and indiscernible from "ourselves" (Balibar 2009, 210). The borderland also contains the potential for 'cultural invention' stemming from the constantly renewed presence of differences. Balibar's vision of a borderland Europe is based on the idea that Europe is heterogeneous and differs from itself. I would add that it is exactly the heterogeneity of the supposedly 'unfit', the 
pariahs and the parasites - and not all differences as Balibar seems to implythat is crucial for making the borderland a normative term.

Apart from some rather general considerations about translation and mediation Balibar does not indicate precisely how such creativity might emerge (see also Balibar 2003). Using Mary Louise Pratt's influential term, we can speak of borderlands as 'contact zones' where differences are not easily neutralized and mastered. The stakes are higher in the contact zone, but so are the potentials. The contact zone is the social space where actors, by meeting, clashing, and grappling with each other, negotiate their differences (Pratt 2007, 7). Conditions are often unequal - as in colonization or migration - and strategies include resistance, rejection, assimilation, and imitation. Pratt, however, also points to other effects of contact. Even in highly asymmetrical circumstances, we might find effects of transculturation, that is, ways that subordinated groups 'select and invent' from the dominant culture (Pratt 2007, 7). Transculturation thus highlights the creative force of the subaltern. We can see this as a process of translation - the master metaphor for intercultural contacts - that points to the efforts of taking each other seriously. The subalterns are speaking back in ways that not only disclose the hollow nature of abstract universalism, but also introduce new forms of living together and of a future beyond current forms of co-existence.

If we are to transcend the nationalist and racist supplement of the European liberal state, where new forms of brutalism take shape in the desperate efforts to control unwanted bodies (Mbembe 2020) that further expose the hollowness of Europe's so-called universal values, we need to listen to the voices of others. The others are here to tell their stories of Europe. Even when being silenced, interned, and reduced to pure bodies, they continue their resistance nonetheless. They are mobilizing under slogans such as 'let us de-integrate' proposed by the Jewish pariah Max Czollek (2018), 'we are here to stay' launched by refugees, or 'we are here because you were there' already used by migrant activists in the UK in the 1970s (Grantham and Miller 2017). In a post-war Europe shattered by the Second World War, the anti- and transnationalist projects articulated through European integration contained promises for the future. These promises, however, never seriously affected the assimilationist and exclusionary dynamics of the European nation-state; neither did they pose the question of a postcolonial Europe. If we are to look for promises for Europe, we must turn to the outsiders, the misfits disturbing our coordinates of citizenship, community, and belonging. Perhaps this is Europe's only hope.

\section{Note}

1 This work forms part of the ECHOES project which has received funding from the European Union's Horizon 2020 research and innovation programme under grant agreement No. 770248.

2 As quoted in The Telegraph, 3 August 2015 ('Calais Migrant Crisis'), https:// www.youtube.com/watch?v=AsTTTbYT1NU (accessed 29 April 2021). 


\section{References}

Adamson, Fiona B. 2011. 'Engaging or Contesting the Liberal State? 'Muslim' as a Politicised Identity Category in Europe." Journal of Ethnic and Migration Studies 3 (6): 899-915.

Anidjar, Gil. 2013. "On the European Question." Belgrade Journal of Media and Communications 2 (3): 37-50.

Arendt, Hannah. 1944. “The Jew as Pariah.” Jewish Social Studies 6 (2): 99-122.

Arendt, Hannah. 1958. The Origins of Totalitarianism. New York: Meridian Books.

Arendt, Hannah. 1969. On Violence. Boston: Houghton Mifflin Harcourt.

Arendt, Hannah. 1994. Essays in Understanding, 1930-1954: Formation, Exile, and Totalitarianism. New York: Schocken Books.

Arendt, Hannah. 2007. The Jewish Writings, edited by Jerome Kohn and Ron H. Feldman. New York: Schocken Books.

Balibar, Étienne. 1991. "Is There a 'Neo-racism'?” In Race, Nation, Class: Ambiguous Identities, edited by Etienne Balibar and Immanuel Wallerstein, 17-28. London: Verso.

Balibar, Etienne. 2003. "Europe: Vanishing Mediator.” Constellations 10 (3):312-38.

Balibar, Étienne. 2009. "Borderland Europe." Environment and Planning D: Society and Space 27: 190-215.

Beck, Ulrich, and Edgar Grande. 2007. European Cosmopolitanism. Cambridge: Polity Press.

Bein, Alex. 1964. "The Jewish Parasite: Notes on the Semantics of the Jewish Problem, with Special Reference to Germany.” The Leo Baeck Institute Year Book 9 (1): 3-40.

Bernstein, Richard J. 1996. Hannah Arendt and the Jewish Question. Cambridge: MIT Press.

Bhambra, Gurminder. 2009. "Postcolonial Europe, or Understanding Europe in Times of the Postcolonial." In The SAGE Handbook of European Studies, edited by Chris Rumford, 69-85. London: SAGE.

Birt, Jonathan. 2009. "Islamophobia in the Construction of British Muslim Identity Politics." In Muslims in Britain: Race, Place and Identities, edited by Peter Hopkins and Richard Gale, 210-27. Edinburgh: Edinburgh University Press.

Bracke, Sarah, and Luis Manuel Hernández Aguilar 2020. "They Love Death as We Love Life': The 'Muslim Question' and the Biopolitics of Replacement." The British Journal of Sociology 71 (4): 680-701.

Brown, Wendy. 2004. "Tolerance and/or Equality? The 'Jewish Question' and the 'Woman Question'." Differences: A Journal of Feminist Cultural Studies 15 (2): $1-31$.

Buettner, Elizabeth. 2016. Europe after Empire: Decolonization, Society, and Culture. Cambridge: Cambridge University Press.

Burton, James, and Daisy Tam. 2016. "Towards a Parasitic Ethics." Theory, Culture \& Society 33 (4): 103-25.

Césaire, Aimé. 1972. Discourse on Colonialism. New York: Monthly Review Press. Originally published as Discours sur le colonialisme. Paris: Édition Réclame, 1950.

Cheyette, Bryan. 2005. "Frantz Fanon and Jean-Paul Sartre: Blacks and Jews." Wasafiri 20 (44): 7-12.

Cromer. 1913. The Earl of Political and Literary Essays. London: Macmillan.

Czollek, Max. 2018. Desintegriert Euch!. Munich: Carl Hanser Verlag. 
Dadusc, Deanna. 2017. "Squatting and the Undocumented Migrants' Struggle in the Netherlands." In Migration, Squatting and Radical Autonomy, edited by Pierpaolo Mudu and Sutapa Chattopadhyay, 275-84. London: Routledge.

De Genova, Nicholas. 2016. "The European Question: Migration, Race and Postcoloniality in Europe." Social Text 34 (3): 75-107.

El-Tayeb, Fatima. 2008. “The Birth of a European Public': Migration, Postnationality, and Race in the Uniting of Europe." American Quarterly 60 (3): 649-70.

Fanon, Frantz. 1986. Black Skin, White Masks. London: Pluto Press. Originally published as Peau noire, masques blancs. Paris: Seuil, 1952.

Fanon, Frantz. 2004. The Wretched of the Earth. New York: Grove Press.

Fornäs, Johan. 2012. Signifying Europe. Bristol: Intellect.

Gibson, Nigel C. 2003. Fanon: The Postcolonial Imagination. Cambridge: Polity Press.

Goldberg, David Theo. 2006. "Racial Europeanization." Ethnic and Racial Studies 29 (2): 331-64.

Gong, Gerrit W. 1984. The Standard of "Civilization" in International Society. London: Clarendon Press.

Grantham, Bill and Toby Miller. 2017. "We Hate to Quote Stanley Fish, but: 'There's No Such Thing as Free Speech, and It's a Good Thing, Too.' Or Is It?” In After Charlie Hebdo: Terror, Racism and Free Speech, edited by Gavan Titely, Des Freedman, Gholam Khiabany, and Aurélien Mondon, 223-38. New York: Zed Books.

Ifversen, Jan. 2017. "Time Bandits, Historians, and Concepts of Bad Times." Contributions to the History of Concepts 12 (2): 1-11.

Judt, Tony. 2005. Postwar: A History of Europe since 1945. New York: The Penguin Press.

Katz, Ethan B. 2018. "Shifting Hierarchies of Exclusion: Colonialism, Anti-Semitism, and Islamophobia in European History." Crossroads 65 (3): 357-70.

Kølvraa, Christoffer. 2012. Imagining Europe as a Global Player: The Ideological Construction of a New European Identity within the EU. Brussels: Peter Lang.

Marx, Karl. 1994. "On the Jewish Question.” In Marx: Early Political Writings, edited by Joseph J. O'Malley, 28-56. Cambridge: Cambridge University Press.

Mbembe, Achille. 2020. Brutalisme. Paris: La Découverte.

Meer, Nasar. 2013. "Racialization and Religion: Race, Culture and Difference in the Study of Antisemitism and Islamophobia." Ethnic and Racial Studies 36 (3): 385-98.

Modood, Tariq. 2008. "Muslim Integration and Secularism." In Islam \& Europe: Challenges and Opportunities, edited by Ludo Abicht et al., 85-112. Leuven: Leuven University Press.

Nicolaïdis, Kalypso, Berny Sebe, and Gabrielle Maas, eds. 2014. Echoes of Empire: Memory, Identity and Colonial Legacies. New York: I.B. Tauris.

Norton, Anne. 2013. On the Muslim Question. Princeton: Princeton University Press. Odugbesan, Abimbola, and Helge Schwiertz. 2018. "We Are Here to Stay'-Refugee Struggles in Germany." In Protest Movements in Asylum and Deportation: Between Unity and Division, edited by Sieglinde Rosenberger, Verena Stern, Nina Merhaut, 185-293. Cham: Springer.

Onar, Nora Fischer, and Kalypso Nicolaïdis. 2013. "The Decentring Agenda: Europe as a Post-colonial Power." Cooperation and Conflict 48 (2): 283-303.

Parekh, Bhikhu. 2006. "Europe, Liberalism and the "Muslim Question." In Multiculturalism, Muslims and Citizenship: A European Approach, edited by Tariq 
Modood, Anna Triandafyllidou, and Ricard Zapata-Barrero, 179-203. London: Routledge.

Pratt, Mary Louise. 2007. Imperial Eyes: Travel Writing and Transculturation. London: Routledge.

Prutsch, Markus. 2015. European Historical Memory: Policies, Challenges and Perspectives. European Union. Accessed 21 August 2020. https://www.europarl. europa.eu/RegData/etudes/note/join/2013/513977/IPOL-CULT_NT(2013)513977 (SUM01)_EN.pdf.

Rensmann, Lars. 2006. "Europeanism and Americanism in the Age of Globalization: Hannah Arendt's Reflections on Europe and America and Implications for a PostNational Identity of the EU Polity." European Journal of Political Theory 5 (2): 139-70.

Rothberg, Michael. 2009. Multidirectional Memory: Remembering the Holocaust in the Age of Decolonization. Stanford: Stanford University Press.

Saada, Emmanuelle. 2003. "Citoyens et sujets de l'empire français: les usages du droit en situation coloniale." Genèses 54: 4-24.

Sartre, Jean-Paul. 1948. Antisemite and Jew. New York: Schocken Books. Originally published as Réflexion sur la question juive. Paris: Editions Morihien, 1946.

Scott, David. 1995. "Colonial Governmentality." Social Text 43 (Autumn): 191-220.

Selby, Jennifer A., and Lori G. Beaman. 2016. "Re-posing the 'Muslim Question.", Critical Research on Religion 4 (1): 8-20.

Selinger, William. 2016. "The Politics of Arendtian Historiography: European Federation and the Origins of Totalitarianism." Modern Intellectual History 13 (2): 417-46.

Serres, Michel. 1982. The Parasite. Baltimore: The Johns Hopkins Press.

Yapp, Malcolm Edward. 1992. "Europe in the Turkish Mirror." Past \& Present 137: 134-55.

Zeldner, Max. 1953. "A Note on 'Schlemiel'.” The German Quarterly 26 (2): 115-17.

Zolkos, Magdalena. 2011. "Arendt's Metamorphic Figurations in 'The Jew as a Pariah'." In Action and Appearance: Ethics and the Politics of Writing in Hannah Arendt, edited by Anna Yeatman, Charles Barbour, Phillip Hansen, and Magdalena Zolkos, 197-214. New York: Continuum. 